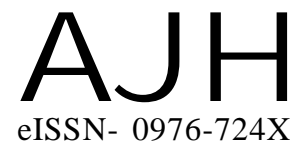

Received : 30.12.2015

Revised : 25.04.2016

Accepted : 05.05.2016
Members of the Research Forum

Associated Authors:

${ }^{1}$ Department of Horticulture, Faculty

of Agriculture, Annamalai

University, Annamalainagar,

CHIDAMBARAM (T.N.) INDIA

${ }^{2}$ Department of Microbiology, Faculty of Agriculture, Annamalai University, Annamalainagar, CHIDAMBARAM (T.N.) INDIA

Author for correspondence : K. HARIPRIYA

Department of Horticulture, Faculty of Agriculture, Annamalai

University, Annamalainagar, CHIDAMBARAM (T.N.) INDIA
THEASIAN JOURNALOF HORTICULTURE

Volume $11 \mid$ Issue $1 \mid$ June, 2016 | 129-13

Visit us -www.researchjournal.co.in

\title{
Effect of organic manures and biofertilizers on the productivity of garden bean [Dolichos lablab (Roxb.) L. var. typicus]
}

J.P. SAJITHA ${ }^{1}$, K. HARIPRIYA, T. UMA MAHESWARI ${ }^{1}$ AND D. STELLA ${ }^{2}$ ABSTRACT : Field experiment was conducted at the vegetable unit of the Department of Horticulture, Faculty of Agriculture, Annamalai University. The study was to find out the effect of organic manures and biofertilizers on the productivity of garden bean cv. KONKAN BUSHAN. The experiment was laid out in a Randomized Block Design with 10 treatments. Each treatment was replicated thrice. Among the treatments tested, inoculation of Rhizobium and vesicular arbuscular mycorrhizae along with vegetable waste vermicompost and foliar supplementation of vermiwash proved superior and recorded significant increase on the growth characters of garden bean such as plant height, leaf area index and dry matter production during both years of crop growth. The same combination of treatments further recorded maximum pod yield $\left(\mathrm{T}_{7}\right)$. As a result of increased nutrient uptake, nodulation and biological nitrogen fixation of Rhizobium, colonization of vesicular arbuscular mycorrhizae and supplement of nutrients through vermiwash and vermicompost (vegetable) and the highest ' $N$ ' content $(3.02 \%)$ of the vegetable derived vermicompost, the treatment $T_{7}$ was found to be superior. These results indicate that the garden bean being a leguminous vegetable crop responds very well for inoculation of Rhizobium, VAM and vermicompost and its wash for providing all necessary nutrients in their available form which in turn leads to the avoidance of inorganic inputs.

KEY WORDS : Vermicompost, Rhizobium, Inorganic inputs

HOW TO CITE THIS ARTICLE : Sajitha, J.P., Haripriya, K., Maheswari, T. Uma and Stella, D. (2016). Effect of organic manures and biofertilizers on the productivity of garden bean (Dolichos lablab (Roxb.) L. var. typicus). Asian J. Hort., 11(1) : 129-131, DOI : 10.15740/HAS/TAJH/11.1/129-131. 